\title{
米 \\ DEVOÇÕES, CATOLICISMO E MUNDO CIBERNÉTICO: SEMÂNTICA NOVA OU ANTIGA PERMANÊNCIA?
}

- EMERSON JOSÉ SENA DA SILVEIRA ${ }^{1}$

${ }^{1}$ Antropólogo. Doutor em Ciência da Religião. Professor no Departamento e Programa de Pós-Graduação em Ciência da Religião da Universidade Federal de Juiz de Fora - UFJF. E-mail: emerson.pesquisa@gmail.com.

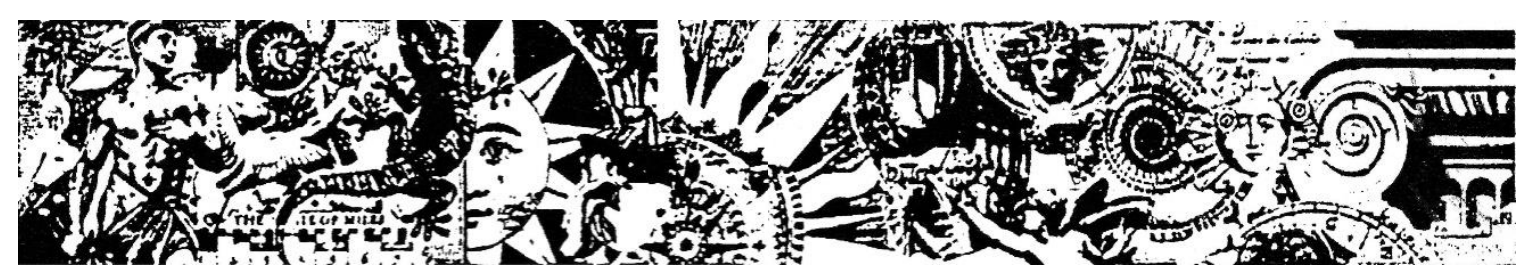

Resumo: No atual contexto de interações entre os vários sistemas religiosos e não-religiosos, as fronteiras possuem contornos incertos, surgem híbridas formas, vistas com estranheza, por atores intelectuais e/ou religiosos. As novas mídias e avanços tecnológicos de comunicação trouxeram mudanças sociais e culturais em todos os campos da vida social, inclusive para a religião católica. 0 ciberespaço e as novas questões que congrega a convergência digital tornaram-se, de forma crescente e complexa, campo em que as religiões e fenômenos religiosos atuam cada vez mais intensamente. Nessa perspectiva, este artigo pretende investigar como se dão as práticas religiosas católicas na internet, as devoções virtuais aos santos entre outras, pesquisando chats, blogues e outros espaços. Quais são as práticas, como elas são feitas, até que ponto elas congregam as velhas tradições, quem as faz e quais as respostas do magistério católico a este movimento são algumas das perguntas centrais, que, a partir de participação observante e pesquisa exploratória pretendemos analisar.

Palavras-chave: Práticas católicas virtuais; Catequese; Memória religiosa. 


\section{DEVOTIONS, CATHOLICISM AND THE CYBER WORLD: NEW SEMANTICS OR OLD PERMANENCE?}

Abstract: In the current context of interactions between various religious and non-religious systems, boundaries have uncertain outlines, hybrid forms emerge, strangely seen by intellectual and / or religious actors. The new media and technological advances on communications have brought about social and cultural changes in all fields of social life, including the Catholic religion. Cyberspace and the new issues surrounding digital convergence have increasingly become a field in which religions and religious phenomena are increasingly active. From this perspective, this article intends to investigate how Catholic practices on the internet occur, the virtual devotions to the saints among others, searching chats, blogs and other spaces. What are the practices, how they are made, the extent to which they congregate the old traditions, who makes them and what are the responses of the Catholic magisterium to this movement are some of the central questions that, from observant participation and exploratory research, we intend to analyse.

Keywords: Virtual Catholic practices; Catechism; Religious memory.

\section{DEVOCIONES, CATOLICISMO Y MUNDO CIBERNÉTICO: ¿NUEVA PERMANENCIA SEMÁNTICA O ANTIGUA?}

Resumen: En el contexto actual de interacciones entre los diversos sistemas religiosos y no religiosos, las fronteras tienen contornos inciertos, aparecen formas híbridas, extrañamente vistas, por actores intelectuales y / o religiosos. Los nuevos medios y los avances tecnológicos en la comunicación han traído cambios sociales y culturales en todos los campos de la vida social, incluida la religión católica. El ciberespacio y los nuevos problemas de convergencia digital se han vuelto cada vez más complejos en los que las religiones y los fenómenos religiosos son cada vez más activos. Desde esta perspectiva, este artículo pretende investigar cómo las prácticas religiosas católicas en Internet, las devociones virtuales a los santos, entre otros, investigando chats, blogs y otros espacios. Cuáles son las prácticas, cómo se hacen, en qué medida reúnen las viejas tradiciones, quién las hace y cuáles son las respuestas de la enseñanza católica a este movimiento son algunas de las preguntas centrales, que desde la participación observadora y la investigación exploratoria pretendemos analizar.

Palabras clave: Prácticas católicas virtuales; Catequesis; Memoria religiosa.

\section{Introdução}

As práticas religiosas do catolicismo brasileiro constituem-se, na atualidade, foco de interesse de muitos pesquisadores. A diversidade temática no interior deste campo, assim como as possibilidades de abordagens, tem contribuído, nas últimas décadas, para a ampliação crescente de trabalhos que buscam compreender tal fenômeno. Desta forma, o artigo que ora é apresentado é mais uma contribuição neste sentido.

Fugindo do espaço tradicional de uma comunidade particular territorializada, a pesquisa se direciona para o espaço virtual no qual os devotos reinventam sua experiência religiosa fazendo uso de novas ferramentas, sem descartar as heranças de suas fontes primeiras, ou seja, as 
tradições trazidas pelos colonizadores, herdeiros de uma prática medieval. Nesse sentido, serão tomadas como exemplos, duas páginas eletrônicas: a do padre "pop star" Marcelo Rossi e a da primeira santa brasileira.

\section{Práticas católicas brasileiras: herança das tradições medievais}

O primeiro esforço registrado para a compreensão das práticas católicas populares no Brasil foi dado por um grupo de pesquisadores reunidos na V Semana Teológica de Petrópolis, realizada sob a coordenação do então Frei Leonardo Boff, no ano de 1976. Fruto deste encontro foi publicado na REB (Revista Eclesiástica Brasileira), no mesmo ano, um fascículo especial, com diversos artigos que versam sobre o 'catolicismo popular', título da edição especial (CATOLICISMO POPULAR, 1976).

É possível notar que os autores, ao abordarem o tema do 'catolicismo popular' e suas práticas, necessariamente fazem referência ao chamado 'catolicismo oficial'. Neste sentido, o fascículo torna-se enriquecedor, podendo ser considerado como ponto de partida seguro para todos aqueles que desejam se aventurar pela temática. Diversas áreas das Ciências Humanas encontram-se representadas na edição, como a História, a Sociologia, a Psicologia e a Teologia elemento expressivo que, já naquele momento, os estudiosos procuravam compreender 0 fenômeno das práticas religiosas católicas numa abordagem interdisciplinar. ${ }^{2}$

Para o nosso trabalho, além da compreensão das práticas religiosas virtuais e o uso de novos instrumentos na atualidade, interessa-nos também a percepção destas práticas como herdeiras da tradição luso-portuguesa, que se transformam ou se renovam diante de novas tecnologias. Portanto, neste primeiro momento, vale ressaltarmos a nossa compreensão de memória religiosa, que deve ser como entendida conforme Halbwachs (1990), como um fio condutor que, ao ligar sujeitos individuais ou grupos sociais, renova suas lembranças num movimento contínuo. A memória nesse sentido é viva e vivida de forma permanente no tempo, sendo as representações-vivências do passado, no caso do campo das práticas religiosas católicas, tantas quanto o número de grupos existentes, renovando-se no espaço das vidas.

Os estudiosos que publicaram no fascículo especial da REB, citado acima, também entendem a memória conforme Halbwachs (1990). O primeiro aspecto que se deve levar em conta ao iniciar os estudos sobre o catolicismo na colônia, tanto o oficial quanto o popular, é sua herança

\footnotetext{
2 Riolando Azzi, Eduardo Hoonaert, Pedro Ribeiro de Oliveira, Edênio Valle, Leonardo Boff, João Batista Libânio e Alberto Antoniazzi são alguns dos autores (CATOLICISMO POPULAR, 1976). 
medieval. A "maioria das devoções são trazidas da terra mãe, bem como o gosto pelas procissões, o hábito das romarias e a crença nos milagres" (AZZI, 1976, p. 96).

Os brasilianistas que se interessam pela temática seguem a mesma direção ao analisar 0 fenômeno. Neste sentido vale destacar a obra de Weckmann (1993), que logo no início do texto destaca dez frutos tardios do espírito medieval na colônia portuguesa, entre eles as formas populares de tradição cristã e a devoção à Virgem Maria. ${ }^{3}$

Em nenhum destes textos encontramos uma referência explícita ao conceito de memória de Halbwachs (1993) e ao conceito de longa duração de Braudel (1992), cujos referenciais teóricos nos fazem compreender as permanências das práticas medievais no além-mar, dos antigos hábitos de pensar e de agir, como elementos estáveis de uma infinidade de gerações. Porém, podemos afirmar que todos os autores se aproximam desses pressupostos em suas análises.

Um dos documentos mais importantes publicados no período colonial pela hierarquia da Igreja Católica 'Constituições primeiras do Arcebispado da Bahia', detecta de forma profunda a permanência desta memória religiosa no Brasil (VIDE, [1707] 2007). Ritos penitenciais medievais que se ligavam mais ao paganismo que a fé cristã descritos por Vauchez (1995), são facilmente encontrados nas 'Constituições Primeiras'. A convicção de que o esforço feito pelo homem por Deus e pelos santos de sua devoção obrigava a potência divina a se revelar a seu favor, levam os fiéis a uma diversidade de práticas que, na visão dos bispos reformados, foram motivos de normas de regulamentação.

Entretanto, deve-se sublinhar que não se trata de uma simples transposição de práticas devocionais, nem mesmo de um modelo de retorno, mas da presença de estruturas históricas de longa duração que deixam transparecer elementos medievais que se atualizam diante de um novo contexto espacial e temporal.

\section{Espaço virtual, religião e catolicismo: transformações e tendências.}

Hervieu-Léger (2008), ao comentar sobre as identidades religiosas herdadas, argumenta que a transmissão das instituições, valores e crenças de um grupo ou sociedade para as gerações posteriores é fundamental para sua continuidade no tempo, sofreu profundas transformações.

Continuidade não significa imutabilidade, como afirma Hervieu-Léger (2008, p. 57), "em todas as sociedades, a continuidade é garantida sempre na e pela mudança". A forma como a

3 Outros elementos são notados: arte de navegação, escolasticismo no ensino, debates teológicos, regimes administrativos, estrutura social, câmaras municipais, tecnologias e processos produtivos entre outros. Cf. Weckmann (1993, p. 18). 
memória, os valores e as crenças religiosas institucionais são transmitidos sofreram rupturas. Não há transmissão sem crise da mesma transmissão, mas na modernidade, com o advento do pluralismo religioso e das esferas de valores e institucionais, com a secularização, a formação do Estado e dos mercados modernos, a herança religiosa sofrerá sucessivos abalos.

Com a radicalização das transformações culturais e sociais na modernidade ocidental, entre elas o vigoroso crescimento de mídias cibernéticas e da comunicação mediada por computador, as instituições nas quais se dava a continuidade da memória e dos valores entre as gerações perdem importância para uma sociabilidade da experiência partilhada, da comunicação direta e do engajamento pontual (HERVIEU-LÉGER, 2008). Nesse sentido, as lacunas observadas entre o "universo cultural das diferentes gerações não correspondem mais apenas aos ajustamentos que a inovação e a adaptação aos novos dados da vida social exigem", verdadeiras rupturas culturais atingem a relação com o mundo, especialmente a capacidade de comunicação dos indivíduos (HERVIEU-LÉGER, 2008, p. 58).

Nesse sentido, o culto aos Santos e a Virgem Maria, tradicionais práticas católicas, antes vividas nos contextos de sociabilização católicas das famílias e da sociedade, são vividas em novos contextos culturais, em particular o complexo mundo da comunicação mediada por computador ou internet.

Os cultos aos Santos e à Virgem Maria não foram ultrapassados, mas se transformaram com 0 advento de páginas eletrônicas, portais, e uma série de práticas como altares e novenas virtuais. Várias questões podem ser levantadas, entre as quais: de que forma a crise de transmissão da memória e sua transformação afetou o culto aos Santos e à Virgem Maria? Quais as descontinuidades entre as posturas conservadoras da Igreja Católica e o culto aos Santos e a Virgem Maria na internet? Que estratégias técnicas e pastorais são usadas pela instituição ou por seus representantes no sentido de domesticar as trajetórias dos fiéis-internautas ou usuários? Antes de responder a essas questões, faremos uma breve introdução ao debate sobre os espaços virtuais.

A internet, um espaço multidimensional, desde seu surgimento em 1969, vem sendo povoada por uma enorme multiplicidade social e cultural, desde transações financeiras ao cibersexo, de capelas virtuais a práticas mágicas, contabilizando milhões de sítios e um faturamento da ordem de bilhões de dólares (TEIXEIRA, 2000).

No entanto, há quem prefira o uso de termos como "comunicação mediada por computador" para substituir categorias originadas do mundo da informática como a própria noção 
de "internet", tida como apenas a base material ou uma super-rede de computadores interligados que media a comunicação humana (JUNGBLUT, 2004).

Mas, segundo Levy (1999), o ciberespaço se constitui num sistema de infinita progressão, sendo, por isso, o sistema do caos. Tido como a encarnação máxima da transparência técnica, acolhe por seu crescimento incontido, todas as opacidades do sentido. Por isso, inúmeras vezes o ciberespaço desenha a imagem de um labirinto móvel, em expansão, universal sem plano possível (LEVY, 1999). Em relação aos conteúdos, ele os aceita todos, pois se "contenta em colocar em contato um ponto qualquer com qualquer outro, seja qual for à carga semântica das entidades relacionadas" (LEVY, 1999, p. 111). Mas é no ciberespaço que a cibercultura se caracteriza pela simultaneidade da acolhida e da exclusão, das fronteiras e da sua ultrapassagem, da utopia da liberdade e do terror da perda de privacidade.

Paradoxalmente, as tecnologias interativas fazem emergir formas de comunicação próximas a rituais tribais e religiosos e às suas lógicas de participação e pensamentos mágicos. Isso porque, o "ciberespaço permite [...] a convivência simultânea das mais diversas comunidades, construindo novas formas de comunicação, interação e simbologia" (LEVY, 1999, p. 240).

Outro aspecto relativo aos espaços virtuais liga-se as categorias técnicas da web, essenciais para entendermos por onde o culto aos Santos e à Virgem Maria se dispersa e se transforma, muitas vezes sem o controle institucional da Igreja. As diferenciações levam a redundâncias, justaposições e desdobramentos. O site ou sítio seria um "local virtual" no qual os recursos de interatividade para o usuário do computador (interface) são realizados por links, ou seja, atalhos digitais que levam o internauta para outra parte do ciberespaço, saindo do endereço eletrônico original.

O portal é uma página eletrônica de extrema complexidade, agrupando outros atalhos como blogues, webtv, rádio, chats ${ }^{4}$, lista de discussão, altares virtuais, tudo em um mesmo endereço na internet, permitindo-se ouvir e ver sons, imagens dinâmicas ou estáticas (ao vivo ou gravadas).

Nesse sentido, o ciberespaço passa a ser o locus em que a instituição religiosa oferece informações e práticas a um usuário que em geral se desconhece quem é, exceto em alguns casos nos quais os usuários de comunidades virtuais deixam testemunhos e registram seus perfis e

\footnotetext{
${ }^{4}$ Segundo Dornelles (2004) o chat é um sistema de comunicação eletrônico com um funcionamento próprio. Ele simula um ambiente, uma sala, por exemplo, em que pessoas conversam. A conversação é dinâmica, seu desenho mantêm algumas configurações básicas, que segundo Dornelles (2004, p. 253) seriam: "a) um campo de preenchimento da mensagem escrita; b) o destinatário (escolhido de uma lista que apresenta os usuários do chat naquele instante) c) 0 modo de envio (aberto a todos ou reservado) e d) mecanismos performáticos digitais padronizados". 
endereços eletrônicos. Porém, sempre é possível simular a identidade, as preferências, as ideias e os nomes. Nunca se está seguro da real identidade do internauta.

A internet se tornou uma poderosa semântica, constituindo uma interatividade livre, de difícil controle e que estabelece distintas direções do processo de comunicação (um-para-todos, todos-para-todos, todos-para-um, um-para-um) com formas mais próximas ou mais distantes em relação às mídias tradicionais. A memória religiosa e as práticas tradicionais sofrem um processo de virtualização o qual institui uma "unidade de tempo sem lugar (graças às interações em tempo real por redes eletrônicas, às transmissões ao vivo) [...] e uma continuidade de ação apesar de uma duração descontínua" (LEVY, 1996, p. 21).

As práticas dos usuários podem ser desdobradas, continuadas, retomadas ou misturadas com outras imagens, ideias e valores independentes do tempo, da origem e da raiz cultural, pois a "sincronização substitui a unidade de lugar, e a interconexão, a unidade de tempo" (LEVY, 1996, p. 21). Isso a despeito da tentativa das instituições de produzirem "normatizações" de trajeto, oferecendo imagens, textos e memórias autorizados.

Nesse sentido, ocorreria a dispersão da memória, submetida a pontos de fuga, recombinações e ressemantizações, mas ao mesmo tempo em que se expande ela é apropriada de múltiplas formas pelos usuários.

O culto aos Santos e à Virgem Maria promovidos por grupos e movimentos populares católicos e, da mesma forma pela hierarquia da Igreja Católica, foi, por esta última, elemento essencial no domínio político-religioso, tornando-se um dos exemplos mais acabados de crença sem pertencimento. Por isso, analisar a atuação da dimensão religiosa do culto aos Santos e à Virgem Maria no mundo virtual é uma tarefa complexa pela própria volubilidade, inconstância, velocidade e multiplicidade das informações que atravessam a rede, constantemente refeitas. Embora as fronteiras sejam móveis e porosas, pretende-se abordar como, do ponto de vista institucional, a lgreja Católica se coloca e propõe sua atuação. Para dar conta dessa análise, será feita uma breve remissão ao catolicismo na internet.

\section{0 catolicismo como página eletrônica}

Se há mais de dez anos havia presença massiva de evangélicos e espíritas na internet, ocorre hoje uma enorme diversificação religiosa, agrupando páginas new age, afro-brasileiras, santo daime, hinduístas, budistas, orientais, seguidores da wicca, devoções a santos, umbandistas, islâmicos e uma interminável lista marcada pela pluralidade religiosa, quase um 
"campo religioso eletrônico". O catolicismo, particularmente no final da década de 1990, acabou penetrando a internet e nela sendo "digitalizado" (LEVY, 1999). Assim, o catolicismo está se expandindo de forma crescente na internet.

A própria instituição católica criou e tem publicado documentos que procuram não só refletir, mas criar um "poder pastoral" dentro dessa realidade eletrônica. Isso é o que pretende o documento 'Igreja e Internet's, publicado em 2002 pelo Pontifício Conselho para as Comunicações Sociais, presidido então pelo bispo americano John Foley.

Outros elementos que apontam para a inserção da milenar instituição religiosa nesses novos processos comunicacionais mediados seria a proclamação oficial de santo Isidoro de Sevilha pelo papa João Paulo II como padroeiro da internet ${ }^{6}$, além da instrução pastoral sobre os recursos e processos a serem usados na internet. ${ }^{7}$

A expansão católica na internet é marcada também pela entrada dos movimentos da Igreja Católica (Renovação Carismática Católica, TFP-Tradição, Família e Propriedade, Fé e Luz, Arautos do Evangelho e outros); das pastorais (Pastoral da Terra, da Criança, Carcerária e outras); dos leigos e dos padres; e das representações institucionais (CNBB-Conferência Nacional dos Bispos do Brasil, arquidioceses, dioceses, institutos de formação e outros).

Há toda uma movimentação em torno da ideia de construir e propagar uma rede católica, fazendo dela uma espécie de presença evangelizadora ou, segundo uma perspectiva mais conservadora, uma catequese eletrônica. Corroborando com essa ideia podemos citar as reuniões pastorais sobre a internet realizados pela $\mathrm{CNBB}^{8}$, além da iniciativa de grupos leigos católicos.

5 Conferir 0 documento no seguinte sítio: <http://www.vatican.va/roman_curia/pontifical_councils/pccs/documents/rc_pc_pccs_doc_20020228_churchinternet_po.html>.

${ }^{6}$ A referência à proclamação desse santo espanhol que morreu em 636 pode ser encontrada em milhares de páginas eletrônicas. Extraímos a referências desta página, <http://www.pavablog.com/2011/07/19/santo-isidoro-de-sevilhaabencoa-os-internautas-faca-a-oracao/>, que contém a seguinte oração: "Deus onipotente e eterno, que nos plasmastes à vossa imagem e nos mandastes buscar tudo quanto é bom, verdadeiro e belo, especialmente na Divina Pessoa do vosso Filho Unigênito, Nosso Senhor Jesus Cristo, concedei-nos, nós vos pedimos, que por intercessão de Santo Isidoro, bispo e doutor, nas nossas viagens através da Internet movamos as mãos e os olhos às coisas que Vos agradam, e acolhamos com caridade e paciência todos quantos encontrarmos. Por Cristo Nosso Senhor. Amém.". 7 Ver documento do Vaticano citado na nota número 3. Há cerca de seis anos atrás a Igreja Católica se manifestou condenando um programa de computador, inventado por um programador católico alemão, um "confessionário virtual", com uma lista de pecados, penitências e outros recursos midiático-eletrônicos aos "pecadores" que quisessem se confessar eletronicamente.

${ }^{8}$ As normas e reflexões sobre a internet encontram-se agrupadas dentro da pastoral da comunicação, iniciativa da CNBB para organizar a ação pastoral católica nos meios de comunicação. Este blogue católico, $<$ http://afamiliacatolica.blogspot.com/2008/07/pastoral-da-comunicao-internet-e-tv.html>, faz uma breve referência ao encontro nacional de pastoral da comunicação em 2008. Nessas referências, destacam-se as metas de implantação da pastoral da comunicação em todas as paróquias brasileiras. Segundo relato do blogue: "O presidente da Comissão Episcopal Pastoral para a Cultura, Educação e Comunicação Social, dom Orani João Tempesta, recordou que, na assembleia de 1997, os bispos do Brasil assumiram o compromisso de criar, até o ano 2000, equipes de Pascom [pastoral da comunicação] em todas as paróquias. 'Estamos atrasados nesse compromisso', disse dom Orani”. Em 2011 essa página eletrônica católica ganhou o "Troféu Blog Cristão". 
Dessa forma, num exame mais amplo das páginas em que o catolicismo aparece como produtor é possível identificar três tipos principais:

a) Páginas institucionais de arquidioceses, dioceses, paróquias, casas de formação, editoras, associações e movimentos que mantêm um sítio, ou blogue, de cunho oficial e formal;

b) Páginas de comunidades e bandas, construídas com os mais diversos estilos e possuindo uma enorme diversidade de recursos interativos entre o usuário e o computador;

c) Páginas pessoais de adeptos ou de personalidades católicas, em especial de padres.

Alguns portais católicos, entre eles o 'Catolicanet', empreendem outros recursos de comunicação com seus potenciais navegadores, as chamadas enquetes, uma espécie de questionário breve, com perguntas simples, diretas, muitas vezes tendenciosas e distorcidas, usadas em outros portais e páginas católicas. Cadastrados no 'Catolicanet' há centenas de sítios e atalhos, nacionais e internacionais, muitos dos quais carismáticos.

A porosidade de dimensões constitui uma estratégia que vai da mímese à interpenetração entre técnicas de comunicação e marketing, além da estética moderna e pós-moderna, adotada por muitos grupos católicos.

Assim uma página denominada Fratres in Unum, ligado a Fraternidade Sacerdotal São Pio $X^{9}$, pretende, por meio de fotos, animações e outros instrumentos, combater desvios morais no catolicismo. O blog é extremamente ativo, com postagens que, conectadas ao Facebook, são curtidas e compartilhadas. No texto eletrônico intitulado, "Francisco, o papa do lobby gay", publicado em 27 de agosto de 2018, o site ultraconservador e reacionário critica o pontificado de Jorge Bergoglio. No texto em questão, há um cartaz da Parada Gay de Maringá (PR) com a imagem do Papa Francisco, emoldurada pelas cores do arco-íris com sua frase sobre os gays ("Quem sou eu para julgar"). O seguinte trecho dá uma ideia do forte reacionarismo:

\footnotetext{
9 Uma organização católica ultraconservadora que nega o Concílio Vaticano II, fundada em 1970 por Dom Marcel Lefebvre e aprovada por outros bispos conservadores como o Bispo de Lausana-Friburgo (Suíça), Dom Charriere. Eles dizem ter recebido em 1971, uma Carta Laudatória do Prefeito da Sagrada Congregação para o Clero, Cardeal Wright. Em 2001, segundo a propaganda deles, contava com 463 sacerdotes, 85 Irmãos, 157 Irmãs, 75 Oblatas, 160 Seminaristas, presente em 30 países com 13 Distritos e 6 Casas Autônomas, 6 Seminários, 159 priorados, 725 igrejas, 83 escolas (desde o Ensino Básico até o Segundo Grau) e 2 universidades, 10 casas de exercícios espirituais. Fonte: http://www.fsspx-brasil.com.br/page\%2001.htm. O sítio atual é: http://www.fsspx-brasil.com.br/exe2/. Nessa nova versão, os dados mudam substancialmente, sendo assim apresentados: "Possui seis seminários, dois pré-seminários (Gabão e Filipinas) e um pequeno seminário (Austrália). É constituída por 161 priorados espalhados por 63 países e servidos por 529 sacerdotes, dos quais a maioria são franceses, guarda a Tradição Católica e busca a vivência na Verdade Imutável. No Brasil, exercendo seu apostolado através de 5 sacerdotes, sem contar os padres e comunidades amigas, a Fraternidade dirige dois Priorados (São Paulo/SP e Santa Maria/RS), diversos centros de Missa e presta auxílio às muitas comunidades amigas tradicionais que o solicitam. Os sacerdotes da Fraternidade celebram exclusivamente a Missa Tradicional, dita de São Pio V, em latim [...] Este Portal na Internet é mantido pelos sacerdotes do Priorado Padre Anchieta, localizado em São Paulo/SP [...] na Vila Mariana..". 
É este relativismo moral, personificado por Francisco em seu trágico simulacro de magistério, que viabilizou esta desgraça cujas consequências amargas se fazem sentir nos Estados Unidos e no mundo inteiro. Não se trata apenas de um erro pontual, de um vacilo do primeiro papa latinoamericano. É todo um modelo de Igreja, toda uma imensa e prevalente corrente teológica surgida na primeira parte do século XX que produziu este fenômeno. ${ }^{10}$

Durante a pesquisa na página do Fratres in Unum, similar a forma de um blogue, havia postagens diárias e semanais em que texto e imagem se alternam na tentativa de "catequizar" o leitor. Por sua condição de heteróclito, o espaço cibernético pode abrigar desejos do retorno ao passado, uma utopia às avessas, num saudosismo sem-fim de uma sociedade católica idealizada, uma cristandade poderosa que submetesse as diferenças e divergências em termos de sexualidade, moralidade e afetividade ao controle rígido e ao extermínio.

Um dado técnico observado na maioria absoluta das páginas católicas, embora não exclusivo das mesmas, é a existência de atalhos de compartilhamento com redes sociais (Facebook, Orkut, Twitter), de impressão ou envio por correio eletrônico para outras pessoas ou grupos, além de atalhos para a introdução de comentários das notícias postadas.

Observe-se que, dividido em colunas, a página Fratres in Unum apresentava uma lista com centenas de blogues e sítios católicos ligados, em sua maioria a associações, leigos ou sacerdotes brasileiros, norte-americanos, franceses e espanhóis que reivindicam a tradição católica. Por fim, os portais mais equipados, possuem um atalho para as chamadas enquetes eletrônicas. No caso desse sítio específico, a enquete em voga era sobre o apoio, parcial ou total, ou a rejeição ao Terceiro Plano Nacional de Direitos Humanos, do Governo Federal, considerado como ofensivo aos valores cristão-católicos. Com óbvia previsibilidade, a maioria dos quatro mil votos, três mil e quinhentos, rejeitava o Plano.

Há muitos outros sítios ultraconservadores, alguns ligados a Igreja Católica na cidade de Campos (Rio de Janeiro) e outros ligados a associações ultraconservadoras como a Associação Monfort, ${ }^{11}$ mantida por um antigo membro da TFP ou a Frente Universitária Lepanto, ${ }^{12}$ de estudantes universitários católicos, em cuja página de auto apresentação. Na internet, convivendo com os ultraconservadores, os sítios ultraliberais católicos, como o das Católicas pelo Direito de

10 FRATRES IN UNUM. Francisco, o papa do lobby gay. 27 ago. 2018. Disponível em: < https://fratresinunum.com/2018/08/27/francisco-o-papa-do-lobby-gay/> Acesso em 22 nov. 2018.

11 Conferir: http://www.montfort.org.br/. O copyright na página compreende os anos de 1999-2011. Fundado pelo professor Orlando Fedeli, apresenta-se como uma associação cultural de católicos que, embora sem ligação oficial com a hierarquia (mas com o apoio de padres e leigos), se vê em uma luta em defesa da Igreja Católica e de seus ensinamentos tradicionais.

12 Conferir: https://lepanto.com.br/quem-somos/. A página é mantida por estudantes universitários católicos conservadores. 
Decidir, ${ }^{13}$ que, assumindo-se como uma entidade feminista inter-religiosa representa um catolicismo liberal, originado de movimentos norte-americanos e europeus que defendem posições feministas e favoráveis ao aborto e aos direitos sexuais das mulheres.

A descrição dos sítios revela registros personalistas como o Fã-clube Amo Padre Genivaldo, com fotos e direito a um blogue, uma espécie de diário virtual, mantido por fiéis seguidores. ${ }^{14}$

A maioria dos sítios de padres está relacionada àquilo que Carranza (2011) denomina de catolicismo midiático, como o do Padre Reginaldo Manzotti, anunciado no Facebook como 'o padre que reúne multidões', ${ }^{15}$ ambos de São Paulo. A maior parte desses sacerdotes é ligada ao movimento carismático, ou são simpatizantes.

Os padres carismáticos famosos como Padre Marcelo Rossi e Padre Jonas Abib possuem páginas com um alto índice de acessos, em torno de milhares, diários e mensais. A estrutura das páginas mantém certo padrão: incluem álbum de fotos, chats, mural de mensagens, notícias, coluna de artigos ou crônicas escritas pelos respectivos padres ou convidados, altares virtuais, atalhos para pedidos de oração, horários de missa, atalhos para outras páginas católicas, música, divulgação de livros, CDs e DVDs de produção própria ou de outros.

A simples quantificação dos sítios e portais relacionados ao catolicismo é tarefa inacabável. Primeiro pela quantidade de buscadores ou dispositivos que elencam o endereço eletrônico desses. Segundo porque no próprio espaço virtual há buscadores ligados apenas a sítios religiosos como o buscador 'Busca.católica'. Terceiro, porque os endereços eletrônicos possuem um elevado grau de volubilidade e multiplicam-se antes mesmo que possam ser contados. Quarto, a múltipla inserção das páginas eletrônicas em diversos buscadores

\footnotetext{
${ }^{13}$ Conferir: http://catolicasonline.org.br/. Apresentam-se como uma entidade feminista, de caráter inter-religioso, que busca justiça social e mudança de padrões culturais e religiosos vigentes na sociedade, respeitando a diversidade. Constituiu-se no Brasil em 1993, formalizando-se juridicamente em 1994, e atua em articulação com uma rede latinoamericana (Católicas por El Derecho a Decidir), com Catholics for Free Choice, dos Estados Unidos, e com companheiras na Espanha.

${ }^{14}$ Nesse mesmo sítio citado, existe um atalho chamado "As maravilhas de Deus - Testemunhos de vida", em que as pessoas contam graças ou dão testemunhos. Selecionei esta fala que expressa um modo de contato muito pessoal, emotivo, característico da relação "virtual" entre fiéis e sacerdotes carismáticos no ambiente virtual. Diz a pessoa: "Haviam sempre me falado do Pe. Antônio Lima e que celebra missa de louvor aos sábados em Santo Amaro perto do Santuário do Pe. Marcelo Rossi, mas nunca tinha ido, e por não conhecê-lo e a gente acaba deixando. Um sábado a noite estava em casa e chamei uma amiga para ir para preencher as horas, fiquei encantada com tudo o que aconteceu. Da música ao momento da adoração. Quando o padre passou perto de mim com o Santíssimo senti um arrepio e olhei para ele e naquele momento em que olhei nos olhos dele foi como se uma paz interior tivesse entrado dentro de mim. Gostei muito. Alessandra - (Campo Limpo)".

${ }^{15}$ Conferir o sítio: <http://www.padrereginaldomanzotti.org.br/>. Na imagem oficial do Facebook, o padre aparece com um microfone na mão com a outra faz o sinal cristão-ortodoxo do Nome do pai. Atrás dele, surge uma multidão compacta de pessoas. Conferir: <http://www.facebook.com/padrereginaldomanzottił!!/padrereginaldomanzotti>. 
simultaneamente. Assim, páginas eletrônicas de culto aos Santos ou à Virgem Maria podem estar inseridas tanto em buscadores católicos, quanto esotéricos e outros.

\section{Dispersão da memória e culto aos Santos e a Virgem Maria}

Apesar da credibilidade e da autenticidade serem sujeitas a polêmicas no meio digital, 0 eixo em torno do qual circulam os discursos, pessoas, informações, formas de construir narrativas e imagens, são hibridizados, porém se constituem como forma de perpetuação de uma memória religiosa que se reinventa no tempo.

Por um lado, a memória e a herança do culto aos Santos e à Virgem Maria desvinculamse de laços territoriais e dos signos a ele associados, sendo retraduzidos em hipertextos. Ocorre, por outro lado, uma reterritorialização em novos signos, numa comunidade virtual, mas agora em outro sentido de espaço e tempo.

Por isso, para exemplificar as questões aqui levantadas, serão abordados e descritos, duas páginas eletrônicas, a de um padre católico carismático de grande projeção e a de um santuário dedicado a uma santa brasileira. A escolha destas deve-se ao fato de representarem tanto elementos do catolicismo oficial como do denominado popular.

a) A página do padre Marcelo Rossi.

Segundo os dados fornecidos por seus produtores, a página existe e é uma campeã de acessos e utilização por fiéis-usuários ou internautas-simpatizantes desde 2003. Trata-se de um portal, com toda parafernália cibernética: capela, rosário, terços e velas virtuais, notícias, artigos, pedidos de oração, chat, rádio e webtv, fotos da construção do novo santuário da Mãe de Deus, pequena relação de sítios católicos, testemunhos, música e, claro, propaganda de seu livro mais vendido, Ágape, com mais de quatro milhões de cópias vendidas. Aliás, a barra inicial da página eletrônica começa com a foto do livro, que é uma imagem do sacerdote com um terço na mão, e uma chamada: "Mega promoção do nosso livro Ágape. Apenas 9,90 e na compra de 3 ou mais livros no mesmo pedido, o frete é grátis".

Durante o início da navegação uma música suave e intimista é tocada: "A minha vida é do Mestre, meu coração é do meu Mestre, minha esperança é do meu Mestre [...] as ondas grandes veem tentando me arrastar para longe de sua presença".

De tom azulado, a página é composta de três colunas. A primeira, à esquerda, com atalhos em letras menores, anuncia os horários das missas, fotos, notícias, o histórico, o novo santuário, 
cadastro, sala de imprensa, mensagens do dia, liturgia diária, doações, caravanas e sítios católicos. Na coluna do meio, repetindo alguns nomes dos atalhos da coluna da esquerda, em quadros maiores, há fotos e breve apresentação do atalho: liturgia diária (com uma foto do padre Marcelo erguendo uma Bíblia); notícias (com pequenas fotos do padre Marcelo e do Bispo Dom Fernando Figueiredo); horário das missas no Santuário da Mãe de Deus (com a foto da Virgem Maria segurando e apresentando o Menino Jesus); e finalmente o mosteiro da palavra, versando sobre artigos bíblicos e outros (com a imagem de uma Bíblia aberta). ${ }^{16}$

$\mathrm{Na}$ coluna da direita, em quadros ainda maiores, em tom azulado e com letreiros brancos brilhantes, surgem mais atalhos, repetindo outros existentes. De cima para baixo, havia os seguintes atalhos sob a forma de quadros: cartão virtual, músicas, pedidos de oração, quem somos, testemunhos, capela virtual, santo do dia, novo santuário, cadastro e Facebook. Cada atalho possuía uma frase de estímulo à participação do internauta: 'conheça o perfil de Padre Marcelo e Dom Fernando', 'palavras movem, testemunhos arrastam', 'envie cartões virtuais para quem você ama', 'pedidos de oração, rosários virtuais e velas virtuais', 'conheça a história do santo do dia', 'receba lindas mensagens e orações' e, por fim, 'você no colo de Jesus!'. Cada atalho possui, em cor vermelha, o botão 'clique aqui' para a navegação.

Do ponto de vista institucional há toda uma geografia virtual, uma hierarquização e organização das informações e das imagens. Do ponto de vista do internauta, é possível fazer múltiplos trajetos dentro do sítio sem passar necessariamente por outros atalhos. Assim, caso exista um hipotético internauta que queira apenas acender velas virtuais, isso é possível.

Porém, por conta dessa liberdade de construção do trajeto há uma sutil tentativa de domesticação. Para começar a navegar é preciso realizar um registro inicial, em que são pedidas informações sobre o e-mail, data de nascimento, cidade, estado, telefone com operadora e outros dados, sendo, por fim, obrigatório aceitar o recebimento de, pelo menos, um boletim ou newsletter mensal. Caso isso não seja feito, não é possível navegar plenamente no sítio, ficando-se apenas na página inicial. ${ }^{17}$

Ao fornecer o e-mail é necessário revalidar eletronicamente o cadastro e, para navegar por qualquer outro atalho, é preciso digitar novamente o e-mail num pequeno nicho no centro da página e confirmar apertando o botão do mouse. Imediatamente a navegação é conduzida ao setor desejado. Nesse pequeno quadro branco, acima do nicho, há uma série de frases em

${ }_{16}$ É preciso frisar que os desenhos de páginas como essa, muito acessadas e populares, mudam constantemente. Portanto, deve-se ressalvar que o desenho descrito eletrônico poderá sofrer mudanças entre a época da pesquisa e a publicação deste artigo.

${ }^{17}$ Aceito, 0 usuário necessariamente passará a receber diariamente, em número bastante elevado, mensagens que fazem referências a venda do livro Ágape, terço bizantino, mensagens do dia, entre outros. 
vermelho. A primeira dizia: "Vamos! Venha participar da Rede Eletro-Cristo com Maria", e a seguir, "Junte-se à nossa Família na rede Eletro-Cristo com Maria". Abaixo dessas frases, há o atalho para 0 cadastro. Mas há outras frases, em tons escuros, como "Não se esqueça de adicionar 0 sítio em sua lista de contatos, amigos, lista de confiança para que o AntiSpam não bloqueie as mensagens e orações enviadas diariamente". Por fim, em letras maiúsculas vermelhas: "Evangelizar = Felicidade, Seja feliz, Evangelize!". Durante toda navegação, ao lado da moldura da página, havia imagens distribuídas espaçadamente do livro Ágape, de autoria do padre Marcelo. Essa navegação é emblemática do procedimento de domesticação dos fluxos aleatórios de usuários em alguns sítios eletrônicos católicos.

Para participar do chat de bate papo, digita-se novamente o e-mail de cadastro, e as salas são divididas em amigos, crianças, homens e mulheres, funcionando apenas de oito às vinte horas. Não é permitido escolher o nickname ou apelido virtual: ele é gerado automaticamente a partir do nome escolhido para o e-mail cadastrado. Na página do chat de bate papo, as fotos do bispo de Santo Amaro, Dom Fernando Figueiredo e do padre Marcelo Rossi e sua família (mãe, pai, irmã) estão no centro e com um alerta: se a foto estiver colorida é porque eles estão on line. Na página da webtv, estão vídeos gravados de momentos de missas e dedicatórias de lançamento do livro Ágape em diversas cidades brasileiras. A imagem desta página é emblemática: num plano horizontal, da esquerda para a direita, estão fotos de padre Marcelo paramentado e do santuário, este último sob a forma de uma Bíblia aberta. Por fim, há a imagem de uma pequena escultura da Virgem Maria apresentando seu Filho. A Virgem o segura com uma mão e, com a outra, abre as palmas como se deixasse cair algo.

$\mathrm{Na}$ página que conduz às obras do novo santuário percebe-se a noção de monumentalidade da fé. Ressaltam-se a dimensão das obras e do espaço que agrupará dezenas de milhares de fiéis. Será mais um grande santuário mariano, intitulado Santuário 'Theotokos, Mãe de Deus', na cidade de São Paulo. A mistura do tradicional e do moderno é expressa nas imagens evocadas pelo pequeno texto da página. $O$ texto afirma que "o santuário terá uma cruz de quarenta e dois metros de altura que poderá ser vista de diversos pontos da cidade, simbolizando uma das marcas turísticas da capital paulista". E mais adiante "A novidade será a construção de uma cripta sob o altar". ${ }^{18}$ Após, citam-se a presença de secretários de Estado e da esposa do Governador. $\mathrm{Na}$ verdade, o uso de criptas abaixo do altar é uma antiga tradição cristão-católica, bem como a relação próxima com o poder político. Por outro lado, a cruz como símbolo turístico de um grande

${ }^{18}$ Conferir: http://www.padremarcelorossi.com.br/novosantuario.php 
santuário mariano pode evidenciar tanta uma nova estratégia de transmissão de memória, quando a diluição do significado tradicional.

Para finalizar a breve análise, será descrita a capela virtual. Com bastantes recursos cibernéticos a página se abre e desdobra-se. Há uma música suave e a imagem de uma capela branca, que vai se aproximando na tela até que suas portas se abram e, enfim, surja o Santíssimo Sacramento, corpo de Cristo para os católicos, dentro do sacrário, ladeados por duas velas virtuais grossas acesas. Embaixo dessa imagem do Santíssimo, seguem, um abaixo do outro, os seguintes quadros de cor azulada e branca, com imagens relativas ao terço, a velas coloridas, a Virgem Maria segurando o Menino Jesus, São Miguel e Anjos e a Pomba: Pedidos de oração; Orações (com orações escritas como quebra de maldições); Rosário Virtual; Terço da Misericórdia; Coroa de São Miguel; Terço do Anjo da Guarda; Coroa do Espírito Santo e Vela Virtual. Cada quadro possui uma "chamada" que sempre termina com um ponto de exclamação. Aliás, esse recurso aparece em excesso em todo sítio, inclusive nas mensagens que se recebe ao cadastrar o e-mail para navegar. Um recurso linguístico que expressa uma retórica da sedução, do convencimento, da emoção, do marketing. Nos sítios tradicionais e conservadores, esses recursos são escassos e usados raramente.

$O$ atalho que conduz a página das Velas Virtuais é um capítulo a parte. Todas as velas coloridas são estampadas com a imagem da Virgem Maria segurando seu filho com uma mão e a outra aberta. Acima de cada vela há uma pequena oração, iniciada com a palavra "ágape", tradução grega do amor divino, puro, sem contaminação, desinteressado. Há uma grande vela laranja no meio, e duas do lado esquerdo, branca e vermelha, e do lado direito, verde e roxa. Sobre a vela branca, a oração diz: "Ágape Jesus, eu tenho um sonho...". Sobre a vela verde: "Ágape Jesus, que eu possa realizar esse sonho". Sobre as velas vermelha e roxa: "Ágape Jesus, eu e minha família temos um sonho" e "Ágape Jesus, que eu e minha família possamos realizálo". E por fim, sobre a grande vela laranja: "Ágape Jesus, amor incondicional, amor sem limites, Amor que tudo pode realizar, Amém". Essa vela dura trinta dias. Vale destacar que até o momento da pesquisa, em agosto de 2011, havia quinhentas mil velas virtuais, distribuídas em dezoito mil páginas.

Apenas as orações curtas que estão nas velas ao lado da vela maior mudam de acordo com campanhas e outras orientações feita pelo padre. Durante seu programa de rádio diário, 0 sacerdote paulista cita as velas, o sítio, faz referências ao chat e lê testemunhos. Como lembra Carranza (2011), o catolicismo midiático está em rede e reforça constantemente as passagens 
entre as mídias tradicionais e novas. Na própria página eletrônica é possível acessar o rádio e a televisão, embora o contrário ainda não seja de todo possível.

Em cada vela, que imita o balançar da chama, o internauta pode clicar e acender. Ao entrar pelo atalho, há um espaço na página chamado de "setores de velas" em que estão as velas já acesas por outras pessoas, com nome, data, cidade e estado. Porém, para acender a vela é necessário preencher um pequeno formulário com nome, sobrenome, e-mail, cidade e a intenção. O internauta pode escolher a vela digital de um ou de sete dias. Ao fim da página há uma contagem constante das velas. Para se formar uma ideia da frequência, havia em uma vela virtual de sete dias, cento e quinze mil registros no mês de agosto de 2011.

b) $O$ sítio do Santuário de Madre Paulina ${ }^{19}$.

Dedicado à primeira santa brasileira, possui diferenças substanciais em relação ao sítio do padre Marcelo. Contudo, a estrutura de distribuição do conteúdo é parecida. Imagens do santuário, externas e internas, circulam continuamente numa barra horizontal com os seguintes atalhos: home, o santuário, Santa Paulina, peregrinações, imprensa, missa ao vivo e contato. Interessante é o contraste entre uma pequena foto do casebre em que madre Paulina trabalhou e a foto maior, evidenciando a monumentalidade do santuário. A seguir, duas colunas, a primeira mais estreita, com estes itens: notícias, informativo, atendimento on line e parceiros; a segunda, mais larga, subdividida em duas e com espaços nos quais imagens e chamadas sucedem-se, apagando e surgindo continuamente, seguido destes itens: missionários com Santa Paulina, vídeos, fotos, pedido de oração e contato.

Situado na cidade de Nova Trento, em Santa Catarina, o templo chama atenção pela amplitude e arquitetura em forma de um chapéu de freira. Durante a pesquisa, os atalhos dotados de imagens e chamadas expressam a presença da tradicionalidade católica como este: o título, agosto, mês das vocações acoplado a uma imagem com três partes, um padre ajoelhado diante de um crucifixo, uma família numerosa e uma freira de mãos postas em oração. Na visão tradicional, para homens e mulheres, há apenas duas vocações básicas: casar e constituir uma família ou seguir a vida sacerdotal ou a vida religiosa.

As velas virtuais da página do santuário são mais simples. Abaixo da imagem de uma vela estática de cor alaranjada, está o nome da pessoa que pede. Para acender é preciso preencher um formulário mais simples, com nome, e-mail e pedido.

$19 \mathrm{O}$ site mudou o desenho após a pesquisa. 
Em nenhum dos dois sítios foi possível saber as intenções, acessíveis apenas ao internauta que acendeu sua vela, ao contrário das manifestações escritas e imagéticas dos exvotos tradicionais ou de práticas populares que enchem igrejas católicas nos campos e nas cidades.

No atalho para a página dedicada a santa, o internauta pode ler uma breve biografia da Irmã Paulina e de seu processo de beatificação, na qual chama atenção a imagem da pobreza e da servidão ao Senhor.

Há uma ladainha escrita, tradicional forma invocativa católica, em que, pedindo misericórdia a Jesus Senhor, descrevem-se as qualidades da santa, ora-se o lema "rogais por nós". As invocações eram muitas, entre as quais: 'Seguidora fiel do Deus da Vida, Mulher obediente e corajosa, Irmã dos Pobres, Irmão dos aflitos, irmã de todos os excluídos', entre outros. Percebe-se na linguagem a imagem tradicional sobre a mulher, mas ao mesmo tempo a introdução de termos mais próximos a discursos modernos, como coragem e exclusão.

Ainda na página dedicada à santa, há a novena, com uma breve oração diária. A imagem que emerge dessas orações é a da mulher dedicada ao extremo para com a vida de pobreza acolhendo pessoas necessitadas. Há também um atalho para o calendário de festas: nascimento, morte e canonização. Há outros atalhos que descrevem a estrutura do santuário, a igreja de Vígolo de 1876, onde rezou a santa, outro que apresenta o casebre reconstruído em que está se notabilizou pela acolhida dos pobres e onde ficam os documentos de nascimento, batismo e crisma. Por fim, no atalho sobre a estrutura do santuário, chama atenção o Mosteiro Park, uma espécie de hotel para visitantes.

O texto ressalta as belezas naturais e oferece "inúmeros restaurantes, lojas e hotéis que possibilitam a todos aqueles que visitam o Santuário desfrutar de uma boa estadia". 20

\section{Considerações finais}

O culto aos Santos e à Virgem Maria tem sido através do tempo uma estratégia utilizada pela Igreja Católica para a autoperpetuação da memória e da tradição, substância ontológica dessa instituição religiosa.

Os pontificados de João Paulo II e Bento XVI realizaram centenas de beatificações e canonizações, investiram em meios de comunicação e organizaram a ação pastoral num sentido conservador. Estas ações procuram perpetuar uma memória autorizada a partir da construção de

${ }^{20}$ Conferir: https://www.santuariosantapaulina.org.br/santuario/servicos/ 
santuários e páginas eletrônicas. Os sítios oficiais apresentam a evangelização como vontade de Deus, perene no tempo, mas ao mesmo tempo usam linguagens modernas e subjetivadas.

Por outro lado, as linguagens da tradição e da memória católica se misturam às do marketing, do bem-estar e da felicidade. Os cultos aos Santos e à Virgem Maria tornam o clima familiar, propiciando envolvimento emotivo e, ao mesmo tempo, nota-se a permanência dos sinais católicos como balizadores da navegação dos internautas: rosário, terços, novenas, imagens, velas, ladainhas e outros. Ao lado desse clima, há outro assemelhado as práticas neopentecostais, especialmente pela possibilidade de comércio de produtos de forma bem planejada, empolgante e emotiva.

Com a reconstituição das práticas do catolicismo, tanto de cunho oficial quanto de cunho popular, nota-se que estas permanecem no tempo e, ao serem reinventadas continuadamente em sítios, chats, redes virtuais e outros elementos do mundo cibernético, e assim, busca-se estabelecer continuidade com um passado histórico apropriado (HOBSBAWM, 1997). No caso por nós analisado do culto aos Santos e à Virgem Maria, nota-se a permanência da memória tradicional que liga os fiéis as fontes primeiras do Cristianismo.

Por um lado, se as pessoas se tornam 'não-presentes' porque estão independentes do espaço físico, por outro, o virtual "produz efeitos" nas comunidades imaginárias em que os sinais católicos são apresentados aos navegadores. Em futuras pesquisas, será necessário indagar como os usuários e os fiéis-internautas se relacionam com a tradição católica dispersa, dispersada e reintegrada em páginas eletrônicas, blogues, imagens e textos oferecidos pela instituição.

\section{Referências}

AZZI, Riolando. Elementos para a história do catolicismo popular. Revista Eclesiástica Brasileira. N. 36, Fascículo 141, março/1976, Petrópolis: Vozes, p. 95-130.

BRAUDEL, Fernand. História e Ciências Sociais: a longa duração. In: Escritos sobre a História. 2. ed. São Paulo: Perspectiva, 1992, p. 41-78.

CANCLINI, Néstor Garcia. Culturas híbridas: estratégias para entrar e sair da modernidade. São Paulo: EDUSP, 2000.

CARRANZA, Brenda. Catolicismo midiático. Aparecida do Norte: Ideias \& Letras, 2011. 
CATOLICISMO POPULAR. Revista Eclesiástica Brasileira. N. 36, Fascículo 141, março/1976, Petrópolis: Vozes, 1976.

DORNELES, Jonatas. Antropologia e internet: quando o "campo" é a cidade e o computador é a "rede". Horizontes Antropológicos (Antropologi@Web), Porto Alegre, UFGR, ano 10, n.21, jan.-jun., 2004, p. 243-271.

HALBWACHS, Maurice. A memória coletiva. São Paulo: Vértice, 1990.

HERVIEU-LÉGER, Danièle. O peregrino e o convertido. A religião em movimento. Petrópolis: Vozes, 2008.

HOBSBAWM, Eric. Introdução: A invenção das tradições. In: HOBSBAWM, Eric; RANGER, Terence (Org.) A invenção das tradições. 2 ed. São Paulo: Paz e Terra, p. 07-24, 1997.

JUNGBLUT, Aírton L. Os evangélicos brasileiros e a colonização da internet. Ciencias Sociales y Religión/Ciências Sociais e Religião, Porto Alegre, n. 4, p. 149-166, 2002.

A heterogenia do mundo on-line: algumas reflexões sobre virtualização, comunicação mediada por computador e ciberespaço. Horizontes Antropológicos (Antropologi@Web), Porto Alegre, UFGR, ano 10, n.21, jan.-jun., 2004, p. 97-121.

LÉVY, Pierre. Cibercultura. São Paulo: Editora 34, 1999.

O que é o virtual? São Paulo: Editora 34, 1996.

TEIXEIRA, Patrícia. Igreja católica chega ao "paraíso virtual". O Estado de S. Paulo, 22/06/2000.

VIDE, Sebastião Monteiro da. Constituições primeiras do Arcebispado da Bahia: feitas e ordenadas pelo llustríssimo e Reverendíssimo Dom Sebastião Monteiro da Vide. Brasília: Senado Federal/Conselho Editorial, (1707) 2007.

VAUCHEZ, André. A espiritualidade na Idade Média ocidental: séculos VIII a XIII. Rio de Janeiro: Zahar, 1995.

WECKMANN, Luis. La herencia medieval Del Brasil. México: Fondo de Cultura Econômica, 1993. 